\title{
ANALGESIC ACTIVITY OF PORTULACA OLERACEA LINN. IN EXPERIMENTAL ANIMAL MODELS
}

\author{
Mayanglambam Medhabati1, Paonam Shyamasakhi², Nameirakpam Meena³, Akham Subhalakshmi4 \\ ${ }^{1}$ Assistant Professor, Department of Pharmacology, Regional Institute of Medical Sciences (RIMS), Imphal, Manipur. \\ ${ }^{2}$ Associate Professor, Department of Pharmacology, Regional Institute of Medical Sciences (RIMS), Imphal, Manipur. \\ ${ }^{3}$ Associate Professor, Department of Pharmacology, Regional Institute of Medical Sciences (RIMS), Imphal, Manipur. \\ ${ }^{4}$ Professor, Department of Pharmacology, Regional Institute of Medical Sciences (RIMS), Imphal, Manipur.
}

\section{ABSTRACT}

\section{BACKGROUND}

The objective of the study is to evaluate the analgesic activity of aqueous extract of Portulaca oleracea Linn.

\section{MATERIALS AND METHODS}

The analgesic activity of aqueous extract of Portulaca oleracea (POE 200, 400 and $600 \mathrm{mg} / \mathrm{kg}$ ) was studied using tail flick test in rats and acetic acid induced writhing test in mice for assessing central and peripheral analgesic activity respectively.

\section{RESULTS}

POE significantly decreased the writhing movements in mice. However, POE did not significantly increase reaction time in tail flick test.

\section{CONCLUSION}

POE may have peripheral analgesic action which can be attributed to its flavonoid contents.

\section{KEYWORDS}

Portulaca Oleracea, Analgesic, Aspirin, Pethidine, Prostaglandin, Flavonoids.

HOW TO CITE THIS ARTICLE: Medhabati M, Shyamasakhi P, Meena N, et al. Analgesic activity of Portulaca oleracea Linn. in experimental animal models. J. Evolution Med. Dent. Sci. 2017;6(4):269-272, DOI: 10.14260/Jemds/2017/61

\section{BACKGROUND}

Pain and inflammation remains one of the world's major health problems. ${ }^{1}$ Pain is an unpleasant subjective experience which is a direct response to an untoward event associated with tissue damage. ${ }^{2}$ Tissue injury is the immediate cause of pain as it releases different chemical mediators like prostaglandins, bradykinins, substance-P which act on the nociceptors causing this sensation. Already available opioid analgesics, non-steroidal anti-inflammatory drugs (NSAIDs) and corticosteroids only provide symptomatic relief and suffer from many drawbacks. NSAIDs produced gastric ulcers while corticosteroids are toxic and relapse of the disease noted on discontinuation of therapy. ${ }^{3}$ Hence, novel potent analgesic and anti-inflammatory drugs without considerable side effects from natural sources are under evaluation. According to WHO estimation, about $80 \%$ of the population in developing countries relies on herbal medicines at least for their primary health care. 4 Traditional Indian medical systems such as Ayurveda and Unani rely heavily on plant products. ${ }^{5}$ North-east regions of India are an abode of various medicinal plants which are utilised by local tribes for the treatment of their ailments. The folklore claim of the inhabitants should be scientifically verified with regard to better utility of the medicinal plants from these regions. ${ }^{6}$

Financial or Other, Competing Interest: None.

Submission 22-12-2016, Peer Review 03-01-2017,

Acceptance 06-01-2017, Published 12-01-2017.

Corresponding Author:

Mayanglambam Medhabati,

Assistant Professor,

Department of Pharmacology,

Regional Institute of Medical Sciences,

Imphal, Manipur.

E-mail:drmedhabati@gmail.com

DOI: $10.14260 /$ jemds $/ 2017 / 61$
Portulaca oleracea Linn. (Portulacaceae), known as common Purslane is an annual succulent herb found abundantly all over the valley of Manipur in moist damp habitats. Plant extract is used for the treatment of boils, inflammations, ulcers and liver disease.7,8,9 The plant contains flavonoids. alkaloids and antioxidants. ${ }^{10,11,12}$ It has been reported to possess hypoglycaemic, ${ }^{13}$ antiulcer ${ }^{14}$ and hepatoprotective properties. ${ }^{15}$ In view of the importance of the medicinal plants as a potential source of cheaper, safer and effective remedies for treating diseases and the traditional use of P. oleracea extract (POE) in various disorders, the present study was undertaken with special emphasis on the study of the analgesic activity of its aqueous extract.

\section{MATERIALS AND METHODS}

\section{Plant Material}

The fresh aerial parts of Portulaca oleracea Linn. were collected from local botanical garden during the months of June-July, 2013 identified and a voucher authenticated by Dr. S.C. Sinha, Professor of Botany (retired) Manipur University, where a voucher specimen MUH No.003419 was deposited.

\section{Preparation of Plant Extract}

The plant materials were cleaned and dried under shade. Then, the leaves were separated and powdered by a mechanical grinder and stored in air tight container for future use. $38 \mathrm{~g}$ powder of dried leaves was extracted with distilled water using a Soxhlet apparatus. ${ }^{16}$ The brownish extract obtained was evaporated, shade-dried, scraped out, weighed and stored in glazed porcelain jar for future use. The yield was $35.2 \%$. 


\section{Experimental Animal}

Healthy albino rats of Wistar strain (100-200 g) / Swiss mice (25-30 g) were obtained from central animal house, RIMS, Imphal. The animals were fasted overnight and during the experiment but had water ad libitum. They were divided into 5 groups with six animals in each group. All experimental protocols were approved by the Institutional ethics committee.

\begin{tabular}{|c|c|}
\hline Group & Drugs and Doses \\
\hline I (control) & 2\% Gum acacia in d/w, $1 \mathrm{~mL} / 100$ g, p.o. \\
\hline II (test) & P. oleracea $(200 \mathrm{mg} / \mathrm{kg})$, p.o. \\
\hline III (test) & P. oleracea $(400 \mathrm{mg} / \mathrm{kg})$, p.o. \\
\hline IV (test) & P. oleracea $(600 \mathrm{mg} / \mathrm{kg})$, p.o. \\
\hline V (standard) & $\begin{array}{c}\text { Pethidine }(5 \mathrm{mg} / \mathrm{kg} \text { i.p.), Tail flick test. } \\
\text { Aspirin (100 mg/kg, p.o.), Writhing test. }\end{array}$ \\
\hline
\end{tabular}

\section{Acute Toxicity Testing}

No adverse effect or mortality was detected in mice up to 3 g/kg p.o. of the aqueous extract of Portulaca oleracea Linn. during 24 hours observation period.

\section{Experimental Procedure}

\section{Models for Assessing Analgesic Activity}

Tail Flick Method

The central analgesic activity of POE was studied in tail withdrawal assay, as described by Sheth UK et al, 1972 with slight modification. ${ }^{17}$ Thirty healthy Wistar albino rats (100$200 \mathrm{~g}$ ) with normal reaction time of 3-4 sec were used for the study. The drugs were suspended in distilled water using $2 \%$ gum acacia and administered orally. The volume of medicaments was kept constant at $1 \mathrm{~mL} / 100 \mathrm{~g}$ body weight of the animals. The tail flick latencies (reaction time) of the animal were assessed by analgesiometer. The strength of the current passing through the naked nichrome wire was kept constant at 6 Amps. The distance between the heat source and the tail skin was $1.5 \mathrm{~cm}$. The site of application of the radiant heat in the tail had been maintained at $2.5 \mathrm{~cm}$, measured from the root of the tail for all rats. The time taken by the animal to withdraw (flick) their tail from the hot wire were noted and taken as the 'reaction time'. The cut off reaction time was fixed at 10 secs to avoid tissue damage. Reaction time was recorded at $1 \mathrm{hr}, 2 \mathrm{hrs}$ and $3 \mathrm{hrs}$ after the drug administration.

\section{Acetic acid induced Writhing test}

This experiment was carried out in pre-screened Swiss albino mice weighing between (25-30 g) using 6 animals in each group, according to the method as described by Witkin LB et al.18 They were divided into 5 groups, where group II to IV received POE at the dose rate of 200, 400 and $600 \mathrm{mg} / \mathrm{kg}$ b.wt., respectively (orally) while group $\mathrm{V}$ was administered with the standard drug aspirin (100 mg / $\mathrm{kg}$ p.o.) $1 \mathrm{~h}$ prior to the injection of acetic acid. Writhing was induced ( 60 minutes later) in each mouse by intraperitoneal injection of $10 \mathrm{~mL} / \mathrm{Kg}$ body weight of $3 \%$ acetic acid in distilled water. The number of writhes was counted after 5 min. of injection for 30 mins.

The percentage of protection at each dose level is calculated as follows:

$$
\% \text { Protection }=100-\left(\frac{\text { Experimental }}{\text { Control }}\right) \times 100
$$

\section{RESULTS \\ Analgesic Activity \\ Tail Flick Test}

The analgesic effect of the aqueous extract of Portulaca oleracea Linn. on the tail flick response in albino rats are summarised in Table1.

\begin{tabular}{|c|c|c|c|c|c|}
\hline \multirow{2}{*}{ Group } & \multirow{2}{*}{$\begin{array}{c}\text { Drug \& } \\
\text { Dose } \\
\text { (mg/kg. } \\
\text { Oral) } \\
\end{array}$} & \multirow{2}{*}{$\begin{array}{c}\text { Pre-Drug } \\
\text { Reaction Time } \\
\text { (Sec) }\end{array}$} & \multicolumn{3}{|c|}{$\begin{array}{c}\text { Reaction Time } \\
\text { (sec) after Treatment }\end{array}$} \\
\hline & & & $1 \mathrm{~h}$ & $2 \mathrm{~h}$ & $3 \mathrm{~h}$ \\
\hline I-Control & $1 \mathrm{~mL} / \mathrm{kg}$ & $3.88 \pm 0.04$ & $3.917 \pm 0.04$ & $3.800 \pm 0.04$ & $3.733 \pm 0.12$ \\
\hline \multicolumn{6}{|c|}{ P. oleracea } \\
\hline II Test & 200 & $3.90 \pm 0.06$ & $4.18 \pm 0.1 .5^{*} \#$ & $3.95 \pm 0.07^{*} \#$ & $3.75 \pm 0.04 * \#$ \\
\hline III Test & 400 & $3.75 \pm 0.05$ & $4.08 \pm 0.18^{*} \#$ & $4.09 \pm 0.09^{*} \#$ & $3.81 \pm 0.10 * \#$ \\
\hline IV Test & 600 & $3.85 \pm 0.02$ & $4.01 \pm 0.06^{*} \#$ & $4.06 \pm 0.07 * \#$ & $3.90 \pm 0.05 * \#$ \\
\hline $\begin{array}{l}\text { V Standard } \\
\text { (Pethidine) }\end{array}$ & 5 (i.p.) & $3.78 \pm 0.07$ & $8.67 \pm 0.25^{* * \# \#}$ & $8.58 \pm 0.15^{* * \# \#}$ & $8.38 \pm 0.25^{* *} \# \#$ \\
\hline One way ANOVA & $\begin{array}{c}F \\
\text { d.f. } \\
P\end{array}$ & $\begin{array}{c}2.337 \\
4,25 \\
>0.05\end{array}$ & $\begin{array}{c}167.303 \\
4,25 \\
<0.001\end{array}$ & $\begin{array}{c}497.794 \\
4,25 \\
<0.001\end{array}$ & $\begin{array}{c}223.311 \\
4,25 \\
<0.001\end{array}$ \\
\hline
\end{tabular}

Values are mean \pm SEM, $\mathrm{n}=6$ in each group, ${ }^{*} \mathrm{P}>0.05$ (NS), ${ }^{* *} \mathrm{P}<0.001$ when compared to control and \# $\mathrm{P}>0.05$ (NS), $\# \# \mathrm{P}<0.001$ when compared to pre-drug reaction time.

There was no significant difference between the means of pre-drug reaction time of the different groups $(\mathrm{P}>0.05)$. $\mathrm{POE}$ at 200,400 and $600 \mathrm{mg} / \mathrm{kg}$ did not show any significant $(\mathrm{P}>0.05)$ increase in the mean reaction time at $1 \mathrm{~h}, 2 \mathrm{~h}$ and 3 $\mathrm{h}$ when compared with predrug and control reaction time. However, the standard drug pethidine (5 mg/kg, i.p.) significantly $(\mathrm{P}<0.001)$ increased the mean reaction time at 1 $\mathrm{h}, 2 \mathrm{~h}$ and $3 \mathrm{~h}$ as compared to control.

\section{Acetic acid Induced Writhing}

The analgesic effect of the aqueous extract of Portulaca oleracea Linn. on acetic acid writhing test in albino mice is presented in table 2 . The analgesic activity was determined by observing the number of writhes in the various treated groups. 


\begin{tabular}{|c|c|c|c|}
\hline Group & $\begin{array}{c}\text { Drug dose } \\
\text { (mg/kg), p.o. }\end{array}$ & $\begin{array}{c}\text { No. of Writhing } \\
\text { Movement } \\
\text { (Mean } \pm \text { SEM) }\end{array}$ & $\begin{array}{c}\text { Percentage of } \\
\text { Protection }\end{array}$ \\
\hline $\begin{array}{c}\text { I } \\
\text { Control }\end{array}$ & $25 \mathrm{~mL} / \mathrm{kg}$ & $78.6 \pm 0.42$ & - \\
\hline II Test & 200 & $56.00 \pm 0.36^{*}$ & $28.75 \%$ \\
\hline III Test & 400 & $54.1 \pm 0.35^{*}$ & $31.17 \%$ \\
\hline IV Test & 600 & $46.6 \pm 0.33^{*}$ & $40.71 \%$ \\
\hline $\begin{array}{c}\text { V } \\
\text { Aspirin }\end{array}$ & 100 & $18.1 \pm 0.35^{*}$ & $76.97 \%$ \\
\hline \multicolumn{4}{|c|}{ ONE-WAY ANOVA F 29.375 P<0.001 } \\
df 4, 25 \\
\hline $\begin{array}{c}\text { Table 2. Analgesic Activity of the Aqueous Extract of P. } \\
\text { oleracea on Acetic Acid Writhing Response in Albino Mice }\end{array}$
\end{tabular}

$\mathrm{n}=6$ in each group, ${ }^{*} \mathrm{P}<0.001$ when compared to control.

The test drug at doses of $200 \mathrm{mg} / \mathrm{kg}, 400 \mathrm{mg} / \mathrm{kg}$ and 600 $\mathrm{mg} / \mathrm{kg}$ significantly $(\mathrm{p}<0.001)$ inhibited the writhing counts and showed $28.75 \%, 31.17 \%$, and $40.71 \%$ inhibition of writhing movements. The standard drug aspirin at a dose of $100 \mathrm{mg} / \mathrm{kg}$ significantly $(\mathrm{P}<0.001)$ inhibited the writhing counts and also produced $76.97 \%$ inhibition of writhing movements in comparison to control group.

\section{Statistical Analysis}

All the data obtained from the study were analysed by the analysis of variance (ANOVA) followed by Dunnett's ' $t$ ' test. A probability level of $\mathrm{P}<0.05$ was considered significant.

\section{DISCUSSION}

The present study was carried out to evaluate the possibility of POE in alleviating pain. Any injury or tissue damage is associated with pain and inflammation. Analgesics can act on peripheral or central nervous system. Peripherally acting analgesics act by blocking the generation of impulses at chemoreceptor site of pain, while centrally acting analgesics not only raise the threshold for pain, but also alter the physiological response to pain and suppress anxiety and apprehension. Pain and inflammation are an essential prelude to the repair process. ${ }^{19}$ The Tail flick test is a standard model for evaluating central analgesic activity of a drug in albino rats. Pethidine $(5 \mathrm{mg} / \mathrm{kg})$ was used as standard drug in this study which was also used as a standard drug by other workers.20,21 There was no significant difference between the pre-drug reaction time of the different groups. The test drug at doses of 200, 400 and $600 \mathrm{mg} / \mathrm{kg}$ showed no significant change in the pain threshold $(\mathrm{P}>0.05)$ after $1 \mathrm{~h}, 2 \mathrm{~h}$ and $3 \mathrm{~h}$ of drug administration when compared to the respective control values for that particular hour. The standard drug (pethidine, $5 \mathrm{mg} / \mathrm{kg}$ ) increased the pain threshold significantly at $1 \mathrm{~h}, 2 \mathrm{~h}$ and $3 \mathrm{~h}$ observations which is at par with the finding of Chakraborty A et al., 2004). Pethidine produced analgesia by interfering with spinal reflex to painful stimuli. Hence, the result of the Tail flick test suggest that the extract POE did not possess centrally mediated analgesic activity.

Acetic acid induced writhing test in mice assessed the peripheral analgesic activity of Portulaca oleracea. Acetic acid triggers the production of irritant substances within the peritoneum which caused the writhing response. The standard drug aspirin at $100 \mathrm{mg} / \mathrm{kg}$ produced $76.97 \%$ protection from writhing. The results obtained with the test and standard drugs were significant when compared to the control $(\mathrm{P}<0.001)$. The test drug; however, was found to be less effective than the standard in increasing the pain threshold.

Thus, in the present study the aqueous extract of Portulaca oleracea significantly reduced writhing response in acetic acid induced writhing test, suggesting its peripheral analgesic activity. However, it did not show centrally mediated analgesic effect in the Tail flick test. Presence of various flavonoid compounds were reported in different parts of P. oleracea. ${ }^{10}$ Further flavonoids are known to inhibit the enzyme prostaglandin synthetase. Since prostaglandins are involved in the pain perception and are inhibited by flavonoids, it could be suggested that reduced availability of prostaglandin caused by flavonoids of Portulaca oleracea might be responsible for its analgesic effects.

\section{CONCLUSION}

The present study reveals that the aqueous extract of the $\mathrm{P}$. oleracea leaves has significant peripheral analgesic activity. Further studies are required to identify the active constituents and their exact mechanism of action responsible for analgesic activity.

\section{REFERENCES}

[1] Li RW, Myers SP, Leach DN, et al. A cross-cultural study: anti-inflammatory activity of Australian and Chinese plants. J Ethnopharmacol 2003;85(1):25-32.

[2] Rang HP, Ritter JM, Flower RJ, et al. Analgesic drugs, pharmacology. $8^{\text {th }}$ edn. New Delhi, Churchill Livingstone Elsevier 2016:509-29.

[3] Jaiswal SR, Santakke SD. Experimental evaluation of analgesic and anti-inflammatory activity of simvastatin and atorvastatin. Indian J Pharmacol 2012;44(4):475-9.

[4] Mathur R, Velpandian T. Medicinal plant based health: where is the medicinal constituent? Indian J Pharmacol 2009;41(4):205-6.

[5] Alwashli A, Sobarry M, Cherrah Y, et al. Antiinflammatory and analgesic effects of ethanol extract of Dracaena cinnabari Balf, as endemic plant in Yemen. Int J Pharm Bio Sci 2012;3(2):96-106.

[6] Kumar S, Singh JP, Kumar SS. Phytochemical screening of some plants of Manipur. J Econ Bot Phytochemistry 1990;1:13-6.

[7] Chopra RN, Nayar SL, Chopra IC. Portulacaceae, glossary of Indian medicinal plants. New Delhi, Council of Scientific and Industrial Research 1956:p 202.

[8] Kiritikar KR, Basu BD. Indian medicinal plants. Vol. 3. 2nd edn. In: Kiritikar KR, Basu BD (eds). Dehra Dun, India: International Book Distributors, 1987:2061-2.

[9] Sinha SC. Ficus hispida Linn. Medicinal plants of Manipur. $1^{\text {st }}$ edn. Imphal, Manipur Association of Science and Society (MASS) 1996:77.

[10] Xu X, Yu L, Chen G. Determination of flavonoids in Portulaca oleracea Linn. by capillary electrophoresis with electrochemical detection. J Pharma Biomed Anal 2006;41(2):493-9.

[11] Xiao FY, Lu FE, Xu LJ. Effect of different parts of Portulaca oleracea on the levels of TNF-alpha and IL-6 in the supernatant of cultured adipose cell. Zhongguo Zhong Yao Za Zhi 2005;30(22):1763-6.

[12] Simopoulos AP, Norman HA, Gillaspy JE, et al. Common Purslane-a source of omega-3 fatty acids and antioxidants. J Am Coll Nutr 1992;11(4):374-82. 


\section{Jemds.com}

[13] Sinha BP, Varma SD. Hoppe-Seyler's zeites physiol. Chem 1962;19(3):274-5.

[14] Karimi G, Hosseinzadeh H, Ettehad N. Evaluation of the gastric antiulcerogenic effects of Portulaca oleracea $\mathrm{L}$. extracts in mice. Phytother Res 2004;18(6):484-7.

[15] Ahmad M, Itoo AA, Baba I, et al. Hepatoprotective activity of Portulaca oleracea Linn. on experimental animal model. Int $\mathrm{J}$ Pharm and Pharmceut Sci 2013;5(3):267-9.

[16] Khosla P, Bhanwara S, Singh J, et al. Antinociceptive activity of Azadirachta indica (neem) in rats. Indian J Pharmcol 2000;32(6):372-4.

[17] Sheth UK, Dadkar NK, Kamt UG. Drugs acting on CNS, selected topics in experimental pharmacology. $1^{\text {st }}$ edn. Bombay: Mohanlal B. Kothari Book Depot 1972:124-58.

\section{Original Research Article}

[18] Witkin LB, Heubner CF, Galdi F, et al. Pharmacology of 2amino-indane hydrochloride (SU-8620): a potent nonnarcotic analgesic. J Pharmacol Expt Ther 1961;133(3):400-8.

[19] Shreedhara CS, Vaidya VP, Vegdevi HM, et al. Screening of bauhinia purpurea Linn. for analgesic and antiinflammatory activities. Indian J Pharmacol 2009;41(2):75-9.

[20] Hajare SW, Suresh C, Tandan SK, et al. Analgesic and anti-pyretic activities of Dalbergia sissoo leaves. Indian J Pharmacol 2000;32(6):357-60.

[21] Chakraborty A, Devi RKB, Rita S, et al. The preliminary studies on anti-inflammatory and analgesic activities of Spilanthes acmella in experimental animal models. Indian J Pharmacol 2004;36(3):148-50. 